\title{
Perubahan Postur/Sikap Tubuh Pada Aktivitas Pewarnaan Batik (Colet) Setelah Dilakukan Perancangan Meja Batik Secara Ergonomi Untuk Mengurangi Keluhan
}

\author{
Siswiyanti ${ }^{1}$, Saufik Luthfianto ${ }^{2}$ \\ 1,2 Jurusan Teknik industri, Fakultas Teknik, Universitas Pancasakti Tegal , \\ Jl. Ciumbuleuit 94, Bandung 40141 \\ ${ }^{1}$ siswieyanti@gmail.com, ${ }^{2}$ saufik34@yahoo.com
}

\begin{abstract}
Abstrak
Postur/sikap tubuh pembatik khususnya pada aktivitas pewarnaan (mencolet) dilakukan dengan menjongkok (squating) yaitu kain di letakkan di atas lantai. Keadaan sikap tubuh atau posisi ini menyebabkan pembatik melakukan pekerjaan statis (diam) rata-rata 3 jam per pewarnaan. Hal tersebut dapat menyebabkan kelelahan pada beban otot statis. Dalam rangka mengurangi beban otot statis maka peneliti mencoba untuk merancangan alat alternatif yaitu meja untuk mencolet/menyanting sebagai pengganti gawangan batik. Tujuan penelitian untuk mengetahui tingkat penurunan keluhan musculoskeletal dan kelelahan serta seberapa besar peningkatan produktivitas setelah dilakukan perubahan postur / posisi Pewarnaan (mencolet) di atas lantai menjadi posisi duduk di kursi-meja secara ergonomi. Metode penelitian adalah eksperimen sama subjek. Meja batik memiliki desain yang bisa diatur ketinggian dan kemiringannya serta bisa diputar sehinga memudahkan dalam proses mewarnai (mencolet). Aplikasi ergonomi pada perancangan meja batik memberikan penurunan tingkat keluhan musculoskeletal pada kegiatan pewarnaan (mencolet) sebesar 36,63\%, memberikan penurunan keluhan kelelahan sebesar 16,73\% dan peningkatan produktivitas sebesar $68,18 \%$. Hal ini menunjukkan bahwa perbaikan sikap kerja pembatik postur tubuh menjongkok menjadi posisi tubuh duduk menggunakan kursi-meja dapat mengurangi keluhan sistem musculoskeletal, kelelahan kerja dan meningkatkan produktivitas kerja pembatik.
\end{abstract}

Kata Kunci: aplikasi meja batik, ergonomi, keluhan, produktivitas

\section{Pendahuluan}

Peralatan yang digunakan untuk pewarnaan dengan sistem colet pada kelompok batik tulis Rizki Ayu di Kalinyamat Wetan Kota Tegal menggunakan alas berupa kain/karung goni sesuai ukuran kain $(220 \mathrm{~cm} \times 110 \mathrm{~cm})$, dengan maksud supaya cairan pewarna tidak mengalir saat di colet. Alat lainnya adalah mangkok yang berisi cairan warna dan kuas untuk mencolet. Sedangkan postur/sikap tubuh pembatik menjongkok karena kain di letakkan di atas lantai. Keadaan sikap tubuh atau posisi ini menyebabkan pembatik melakukan pekerjaan statis (diam) kurun waktu 3 jam per pewarnaan. hal tersebut dapat menyebabkan kelelahan pada beban otot statis. Hasil penelitian pendahuluan terhadap 10 orang pembatik pada pewarnaan colet menimbulkan keluhan $60 \%$ merasakan sakit pada leher bagian atas, $50 \%$ pada leher bagian bawah, 50\% bahu kiri, $50 \%$ pada punggung, 50\% pada bokong, $70 \%$ lengan bawah kiri, $60 \%$ pergelangan tangan kanan, 50\% pada tangan kanan, $60 \%$ pada paha kanan, $70 \%$ pada lutut kiri, $80 \%$ pada lutut kanan, $70 \%$ pada betis kiri, $60 \%$ pada pergelangan tangan kiri, $80 \%$ pada pergelangantangan kanan, 60\% pada kaki kiri dan $70 \%$ pada kaki kanan. Atas dasar hasil penelitian pendahuluan, maka peneliti mencoba untuk merancang peralatan (meja dan kursi) untuk pewarnaan (colet) (sebagai alat alternatif) menggunakan antropometri ergonomi. Tujuan penelitian adalah mengetahui sebarapa besar tingkat penurunan keluhan musculoskeletal dan kelelahan setelah dilakukan perubahan postur/posisi 
pewarnaan (mencolet) di atas lantai menjadi posisi duduk di kursi-meja batik secara ergonomi dan mengetahui seberapa besar tingkat produktivitas setelah dilakukan perubahan postur tubuh/posisi pewarnaan (mencolet) di atas lantai menjadi posisi duduk di kursi-meja batik secara ergonomi. Peneliti juga akan menguji terhadap tingkat keluhan musculoskeletal dan kelelahan setelah dilakukan perancangan alat alternatif tersebut. Sumamur (1992) menyatakan bahwa penerapan ergonomi ke dalam sistem kerja telah terbukti mampu meningkatkan produktivitas, kesehatan, keselamatan dan kenyamanan kerja.

\section{Metode Penelitian}

Penelitian ini menggunakan pedoman pengukuran ergonomi data antropometri, yang diukur dari dimensi tubuh manusia (posisi duduk tegak dan posisi duduk samping). Pengukuran dimensi perancangan juga disesuaikan dengan alat dan bahan yang digunakan oleh pembatik pada posisi nyanting/melukis dengan cairan lilin. Subjek penelitian adalah 20 orang pembatik perempuan (dengan nama Kelompok Riski Ayu) yang ada di Kelurahan Kalinyamat Wetan RT 05/RW 01, Kecamatan Tegal Selatan Kota Tegal, yang dipilih berdasarkan teknik random sampling sederhana (Nazir, 2009). Analisis deskriptif pada subjek dilakukan dengan menghitung rerata dan simpang baku untuk masing-masing kriteria yaitu usia, tinggi badan, berat badan, dan pengalaman kerja. Hasil dimensi tubuh dengan pengukuran antropometri akan dianalisis menggunakan: BMI (Body Mass Index), uji keseragaman data, standar deviasi, uji kecukupan data, pengukuran percentil, dan uji kenormalan data (Wignjosoebroto, S., 1992). Penelitian ini menggunakan rancangan eksperimen sama subjek, yaitu rancangan yang observasi variabel dilakukan beberapa kali, yang subyek kontrolnya sekaligus juga berlaku sebagai subyek eksperimen (Pratiknya, 1993). Bagan rancangan penelitian sebagai berikut :

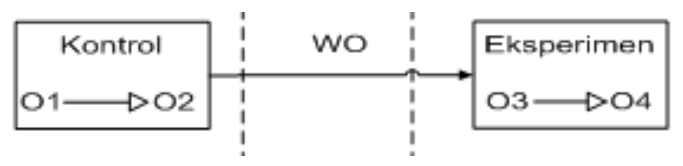

Gambar 1: Rancangan Penelitian

Keterangan :

O1 = Pengukuran kelelahan, keluhan musculoskeletal, dan denyut nadi sebelum bekerja pada kelompok kontrol dengan menggunakan gawangan-dingklik

$\mathrm{O} 2$ = Pengukuran kelelahan, keluhan musculoskeletal, denyut nadi dan produktivitas setelah bekerja pada

kelompok kontrol dengan menggunakan gawangan dingklik $\mathrm{WO}=$ Washing Out (waktu istirahat untuk menghilangkan efek perlakuan sebelumnya agar tidak meninggalkan efek/respon) selama 1 hari.

$\mathrm{O} 3$ = Pengukuran kelelahan, keluhan musculoskeletal, dan denyut nadi sebelum bekerja pada kelompok eksperimen dengan menggunakan meja-kursi hasil perancangan ulang.

$\mathrm{O} 4=$ Pengukuran kelelahan, keluhan musculoskeletal, denyut nadi dan produktivitas sesudah bekerja pada kelompok eksperimen dengan menggunakan meja-kursi hasil perancangan ulang.

\section{Penentuan Jumlah sampel}

Perhitungan besar sampel untuk rancangan dengan subjek yang sama antara kelompok kontrol maupun kelompok eksperimen didasarkan pada rumus dari Sopiyudin (2004) di bawah ini.

$$
N_{1}=\frac{2 x \delta}{\mu_{1}-\mu_{2}} \cdot f(\alpha, \beta)
$$

Hasil penelitian pendahuluan dengan subjek 10 orang diperoleh rerata untuk kuisioner tingkat keluhan musculoskeletal sebesar 56 dan rerata untuk kuisioner kelelahan sebesar 66. Rerata tingkat keluhan musculoskeletal setelah dilakukan perbaikan diharapkan menurun sebanyak $20 \%$ yaitu dari 56 menjadi 44,8 . Sedangkan untuk kelelahan setelah dilakukan perbaikan diharapkan menurun sebanyak $20 \%$ yaitu dari 66 menjadi 52,8. Untuk = 0,05 dan untuk $=0,10$ maka besar sampel (n) untuk tingkat keluhan musculoskeletal adalah sebanyak 11 orang dan untuk kuisioner kelelahan juga sebanyak 16 orang. Besarnya sampel ditambah $20 \%$ untuk menghindari terjadinya drop out subjek penelitian sehingga sampel ditetapkan menjadi 20 orang.

\section{Hasil dan Pembahasan}

Pada gambar 2 adalah posisi menjongkok sebelum dilakukan perancangan ulang mejakursi, yaitu sikap tubuh yang membungkuk dan menjongkok, posisi tubuh menyesuaikan dengan bahan/alat yang dikerjakan sementara lutut ditekuk menjadikan posisi menjongkok menyesuaikan dengan ketinggian lutut sampai kaki. 


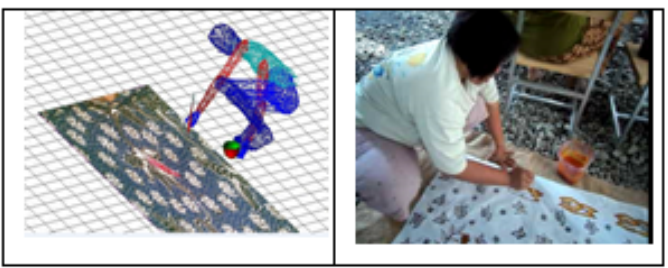

Gambar 2: Sikap/posisi tubuh menjongkok proses pewarnaan (colet) di lantai.

Uji Normalitas Terhadap Dimensi Tubuh

Uji Normalitas untuk menguji data dimensi tubuh dan bertujuan untuk mengetahui apakah sampel berasal dari populasi dengan sebaran distribusi normal. Uji normalitas menggunakan Kolmogorov-Smirnov ditunjukkan pada Tabel 1.

Tabel 1: Rerata, simpang baku dan uji normalitas terhadap dimensi tubuh desain kursi

\begin{tabular}{|c|c|c|c|}
\hline Aspek & Rerata(cm) & Simpangan Baku & p \\
\hline Tinggi Popliteal (TPO) & 35,55 & 3,91 & 0,716 \\
\hline Pantat Popliteal (PP) & 40 & 4,01 & 0,902 \\
\hline Lebar Pinggul (LP) & 38,3 & 2,39 & 0,519 \\
\hline Tinggi Bahu Duduk (TBD) & 41,25 & 2,43 & 0,068 \\
\hline Panjang sandaran (LB) & 40 & 3,04 & 0,759 \\
\hline Lebar sandaran (LS) & 18 & 1,72 & 0,4 \\
\hline
\end{tabular}

Berdasarkan perhitungan, didapat nilai $\mathrm{p}$ pada seluruh aspek lebih besar dari pada 0.05 dengan demikian semua data berdistribusi normal.

Pada Gambar 3 Tata letak peralatan untuk posisi membatik dengan duduk di atas meja memiliki ukuran ketinggian meja yang dapat diatur, dan kemiringan meja bisa mencapai 700. Jangkauan tangan saat mengambil cairan malam melalui kompor sudah disesuikan dengan kedudukan kompor dan kursi. Meja dapat diputar sehingga memudahkan kain bisa dilukis dengan mudah. Tinggi kedalaman meja bagian bawah untuk memudahkan akses kaki. Kedalaman meja untuk kemudahan akses kursi adalah mempertimbangkan agar lutut tidak sampai membentur kedalaman meja (Tarwaka, 2013).

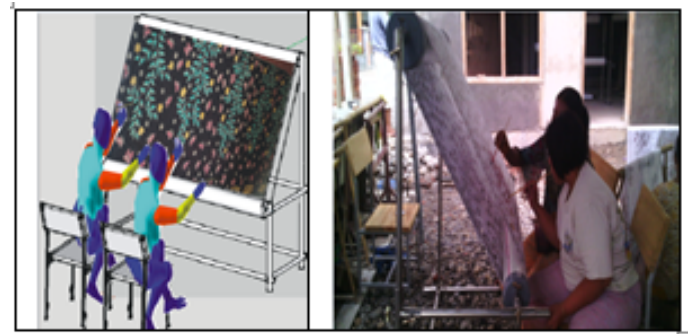

Gambar 3: Sikap/posisi tubuh pada proses pewarnaan (colet) menggunakan meja batik.
Uji Normalitas Terhadap Keluhan Musculoskeletal, Kelelahan, dan Produktivitas

Uji Normalitas untuk menguji data kuisioner tingkat keluhan musculoskeletal kelompok kontrol sebelum beraktivitas, tingkat keluhan musculoskeletal kelompok eksperimen sebelum beraktivitas, tingkat keluhan musculoskeletal kelompok kontrol setelah beraktivitas, tingkat keluhan musculoskeletal kelompok eksperimen setelah beraktivitas, kelelahan kelompok kontrol sebelum beraktivitas, kelelahan kelompok eksperimen sebelum beraktivitas, kelelahan kelompok kontrol setelah beraktivitas, kelelahan kelompok eksperimen setelah beraktivitas, produktivitas kelompok kontrol sebelum beraktivitas, produktivitas kelompok eksperimen sebelum beraktivitas, produtivitas kelompok kontrol setelah beraktivitas, produktivitas kelompok eksperimen setelah beraktivitas. Uji normalitas ini bertujuan untuk mengetahui apakah sampel berasal dari populasi dengan sebaran distribusi normal. Uji normalitas menggunakan Kolmogorov-Smirnov ditunjukkan pada Tabel 2.

Tabel 2: Rerata, simpang baku dan uji normalitas terhadap tingkat keluhan musculoskeletal, kelelahan dan produktivitas pembatik pada kegiatan pewarnaan (colet)

\begin{tabular}{|l|c|c|c|}
\hline Aspek & Rerata(cm) & Simpangan Baku & p \\
\hline $\begin{array}{l}\text { Aspek keluhan } \\
\text { musculoskeletal } \\
\text { kelompok kontrol }\end{array}$ & 70,7 & 3,6 & 0,879 \\
\hline $\begin{array}{l}\text { Aspek kelelahan } \\
\text { kelompok kontrol }\end{array}$ & 69,95 & 2,24 & 0,891 \\
\hline $\begin{array}{l}\text { Aspek produktivitas } \\
\text { kelompok kontrol }\end{array}$ & 0,0044 & 0,0015 & 0,884 \\
\hline $\begin{array}{l}\text { Aspek keluhan } \\
\text { musculoskeletal } \\
\text { kelompok eksperi- } \\
\text { men }\end{array}$ & 44,8 & 4,42 & 0,943 \\
\hline $\begin{array}{l}\text { Aspek kelelahan } \\
\text { kelompok eksperi- } \\
\text { men }\end{array}$ & 58,25 & 3,8 & 0,205 \\
\hline $\begin{array}{l}\text { Aspek produktivitas } \\
\text { kelompok eksperi- } \\
\text { men }\end{array}$ & 0,0074 & 0,0029 & 0,023 \\
\hline$p=$ nilai probabilitas & & \\
\hline
\end{tabular}

Berdasarkan perhitungan, didapat nilai $\mathrm{p}$ pada seluruh aspek lebih besar daripada 0.05 ( p i 0,05) dengan demikian semua data berdistribusi normal.

Tabel 4. menyatakan bahwa tingkat keluhan musculoskeletal, kelelahan dan produktivitas pada sampel didapat nilai probabilitas masingmasing sebesar 0,000; 0,000; dan 0,000 (p i $0,05)$. Dengan demikian dapat disimpulkan bahwa terdapat penurunan yang bermakna antara semua variabel pada kelompok kontrol dan kelompok eksperimen. Perbedaan tingkat keluhan musculoskeletal, kelelahan dan pen- 
Tabel 3: Rerata, simpang baku dan uji normalitas terhadap tingkat keluhan musculoskeletal, kelelahan dan produktivitas pembatik pada kegiatan pewarnaan (colet)

\begin{tabular}{|l|l|l|l|l|l|l|}
\hline Variabel & Kelompok & Rerata & $\begin{array}{l}\text { Simp. } \\
\text { Baku }\end{array}$ & $\begin{array}{l}\text { Beda } \\
\text { rerata }\end{array}$ & t hit & P \\
\hline $\begin{array}{l}\text { Keluhan } \\
\text { Muscu- } \\
\text { loskele- } \\
\text { tal }\end{array}$ & Kontrol & 70,7 & 3,6 & $-25,9$ & 27,389 & 0 \\
\cline { 2 - 5 } & Ekperimen & 44,8 & 4,42 & & & \\
\hline Kelelahan & Kontrol & 69,95 & 2,24 & $-11,7$ & 16,897 & 0 \\
\cline { 2 - 7 } & Ekperimen & 58,25 & 3,8 & & & \\
\hline $\begin{array}{l}\text { Produk- } \\
\text { tivitas }\end{array}$ & Kontrol & 0,0044 & 0,0015 & 0,003 & $-4,748$ & 0 \\
\cline { 2 - 4 } & Ekperimen & 0,0074 & 0,0029 & & & \\
\hline
\end{tabular}

ingkatan produktivitas antara kelompok kontrol dan kelompok eksperimen dapat dilihat pada Gambar 4 Grafik di bawah ini.

Tabel 4: Rerata, simpang baku dan uji normalitas terhadap tingkat keluhan musculoskeletal, kelelahan dan produktivitas pembatik pada kegiatan pewarnaan (colet)

\begin{tabular}{|l|l|l|l|l|l|}
\hline Aspek & $\begin{array}{l}\text { Kel. } \\
\text { kon- } \\
\text { trol }\end{array}$ & $\begin{array}{l}\text { Kel. } \\
\text { eksper- } \\
\text { imen }\end{array}$ & Selisih & Ket. & \\
\hline $\begin{array}{l}\text { Keluhan } \\
\text { musku- } \\
\text { loskelatal }\end{array}$ & 70,7 & 44,8 & $-25,9$ & $-36,6$ & Menurun \\
\hline Kelelahan & 69,95 & 58,25 & $-11,7$ & $-16,7$ & Menurun \\
3 & & 0,0074 & 0,003 & $\begin{array}{l}681,8 \\
18\end{array}$ & Meningkat \\
\hline $\begin{array}{l}\text { Produk- } \\
\text { tivitas }\end{array}$ & 0,0044 & 0 & & & \\
\hline
\end{tabular}

Gambar 4 menyatakan bahwa beda rerata tingkat keluhan musculoskeletal antara kelompok kontrol dan kelompok eksperimen adalah sebesar 25,9 atau terjadi penurunan keluhan musculoskeletal sebesar 36,63\%. Dari hasil kuisioner tingkat keluhan musculoskeletal, didapat penurunan pada keluhan subyektif yaitu sakit pada leher bagian atas dari $40 \%$ menjadi $10 \%$, sakit pada leher bagian bawah dari $80 \%$ menjadi $20 \%$, sakit pada bahu kanan dari $60 \%$ menjadi $30 \%$, sakit pada punggung dari $20 \%$ menjadi $0 \%$, sakit pada lengan atas kanan dari $70 \%$ menjadi $0 \%$, sakit pada pinggang dari $90 \%$ menjadi 10 $\%$, sakit pada bokong dari $60 \%$ menjadi $15 \%$, sakit pada pantat dari $50 \%$ menjadi $10 \%$, sakit pada siku kiri dari 5\% menjadi 0\%, sakit pada siku kanan dari 30\% menjadi 5\%, sakit pada lengan bawah kanan dari $20 \%$ menjadi $0 \%$, sakit pada pergelangan tangan kiri dari $30 \%$ menjadi $20 \%$, sakit pada pergelangan tangan kanan dari $35 \%$ menjadi $0 \%$, sakit pada tangan kiri dari $60 \%$ menjadi 30\%, sakit pada tangan kanan dari 35\% menjadi $25 \%$, sakit paha paha kiri dari $50 \%$ menjadi 5\%, sakit pada paha kanan dari 35\% menjadi $20 \%$, sakit pada lutut kiri dari 50\% menjadi $0 \%$, sakit pada lutut kanan dari $60 \%$ menjadi $0 \%$, sakit pada betis kiri dari $100 \%$ menjadi $15 \%$, sakit pada betis kanan dari $30 \%$ menjadi $20 \%$, sakit pada pergelangan tangan kiri dari $85 \%$ menjadi $5 \%$, sakit pada pergelangan tangan kanan dari $60 \%$ menjadi $0 \%$, sakit pada kaki kiri dari $60 \%$ menjadi $0 \%$ dan sakit pada tangan kaki kanan dari 50\% menjadi 10\%. Perbaikan sikap kerja atau posisi tubuh pembatik posisi duduk di atas meja dapat mengurangi keluhan sistem musculoskeletal pembatik tulis

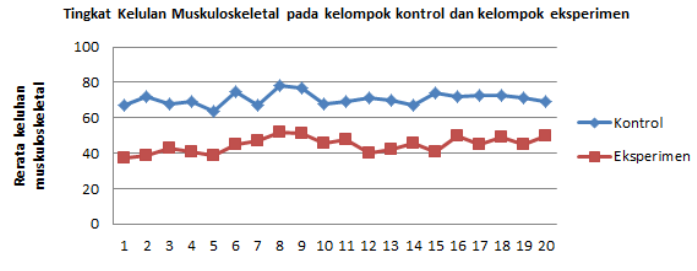

Gambar 4: Tingkat keluhan musculoskeletal pada kelompok kontrol dan eksperimen pembatik pada kegiatan pewarnaan (colet).

Gambar 5 menyatakan bahwa beda rerata antara kelompok kontrol dan kelompok eksperimen adalah sebesar 11,7 atau terjadi penurunan kelelahan sebesar $16,73 \%$. Perbedaan tingkat kelelahan antara kelompok kontrol dan kelompok eksperimen dapat dilihat pada gambar 5 . Dari hasil kuisioner kelelahan, didapat penurunan pada kelelahan yaitu penurunan pelemahan kegiatan dari 55\% menjadi $48,5 \%$, pelemahan motivasi dari $50,5 \%$ menjadi $47 \%$, pelemahan fisik dari 53,5\% menjadi 44\%. Perbaikan sikap kerja atau posisi tubuh pembatik dari posisi duduk diatas meja dapat mengurangi gangguan kelelahan kerja pembatik tulis.

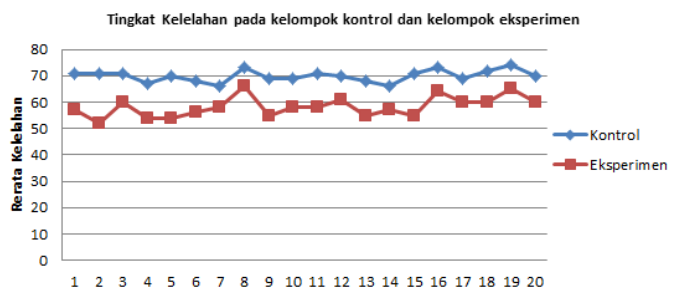

Gambar 5: Tingkat kelelahan pada kelompok kontrol dan eksperimen pembatik pada kegiatan pewarnaan (colet).

Gambar 6 menyatakan bahwa beda rerata antara kelompok kontrol dan kelompok eksper- 
imen adalah sebesar 0,003 atau terjadi peningkatan produktivitas sebesar 68,18 \%. Perbaikan sikap kerja atau posisi tubuh pembatik dari posisi menjongkok di lantai dapat meningkatkan produktivitas kerja pembatik tulis. Hal ini menunjukkan bahwa perbaikan sikap kerja pembatik posisi tubuh jongkok menjadi posisi tubuh duduk yang menggunakan meja batik dapat mengurangi keluhan sistem musculoskeletal, kelelahan kerja dan meningkatkan produktivitas kerja pembatik. Sesuai dengan pernyataan Sumamur (1992) yang menyatakan bahwa penerapan ergonomi ke dalam sistem kerja telah terbukti mampu meningkatkan produktivitas, kesehatan, keselamatan dan kenyamanan kerja.

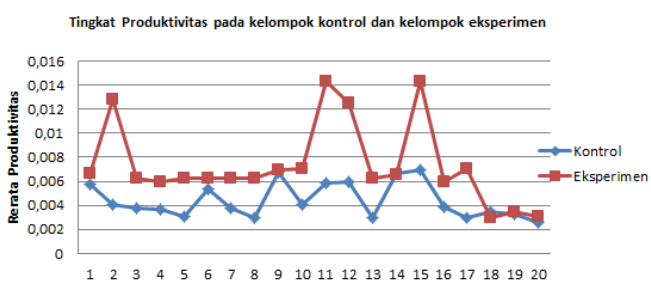

Gambar 6: Tingkat produktivitas pada kelompok kontrol dan eksperimen pembatik pada kegiatan pewarnaan (colet).

\section{Kesimpulan}

Dari penelitian ini dapat diambil kesimpulan sebagai berikut:

1. Meja batik didesain secara ergonomi mempertimbangkan desain kursi dan pelindung kompor. Meja batik memiliki desain yang bisa diatur ketinggian dan kemiringannya mencapai $70^{\circ}$ serta bisa diputar sehinga memudahkan dalam proses pewarnaan (COlet).

2. Aplikasi ergonomi pada perancangan meja batik memberikan penurunan tingkat keluhan musculoskeletal pada kegiatan pewarnaan (colet) sebesar 36,63\%, dan memberikan penurunan keluhan kelelahan sebesar $16,73 \%$..

3. Aplikasi ergonomi pada perancangan meja batik memberikan peningkatan produktivitas sebesar $68,18 \%$.

\section{Daftar Pustaka}

Clarkson, T. W., Magos, L., \& Myers, G. J. (2003). The toxicology of mercury current exposures and clinical manifestations. The New England Journal of Medicine, 349:1731-7.

Clark, D.R. 1996. Workstation Evaluation And Design. Dalam : Battacharya, A. \& McGlothlin, J.D.eds. Occupational Ergonomic. Marcel Dekker Inc.USA : 279-302.

Grandjean, E. 1993. Fitting the Task to the Man. 4th ed. London: Taylor \& Francis Ltd.

Nazir, M. 2009. Metode Penelitian. Jakarta : Ghalia Indonesia.

Pratiknya, A. W. 1993. Dasar-Dasar Metodologi Penelitian Kedokteran dan Kesehatan. Jakarta : Raja Gravindo Persada.

Pulat, BM. 1992. Fundamental of Industrial Ergonomic. New Jersey : Prectise Hall Englewood Cliffs.

Sopiyudin, D. 2004. Statistika untuk Kedokteran dan Kesehatan, Uji Hipotesis dengan Menggunakan SPSS Seri 1. Jakarta : PT. Arkan.

Sumamur, P.K. 1987. Hiperkes Keselamatan Kerja dan Ergonomi. Jakarta : Dharma Bakti Muara Agung.

Sumamur, P.K. 1992. Ergonomi ntuk Produktivitas Kerja. Jakarta : Yayasan Swabhawa Karya.

Tarwaka. 2013. Ergonomi Industri. Surakarta : Harapan Press.

Wignjosoebroto, S. 1992. Teknik Tata Cara dan Pengukuran Kerja. Jakarta :Penerbit Guna Widya. 